\title{
ESFERA PÚBLICA, MÍDIA E CIDADANIA
}

Antonio Teixeira de Barros*

\begin{abstract}
SINTESE - Considerações sobre as categorias de público e privado, com vistas a uma abordagem mais ampla sobre a relaçăo entre esfera pública, midia e cidadania no Brasil contemporâneo. Para tanto, remete-se ao legado teórico de Hannah Arend e Habermas, a fim de fundamentar a caracterização do momento pósburguês da Esfera Pública e o panorama atual.
\end{abstract}

ABSTRACT - This essay analyses the concepts of public and private with the aim to discuss, in a wide scope, the relation among public sphere, media and citizenship in the contemporary Brazil. The author refers to the theoretical legacy of Hannah Arendt and Habermas, with the purpose of supporting the characterization of the post-burgeoning period of the Public Sphere and its current context.

\section{Introdução}

Vivemos em uma época em que os atributos público, coletivo, bem comum, enfim tudo o que é de interesse público parece ser cada vez mais suplantado pelos atributos da vida privada. Estudos históricos demonstram que a Esfera Pública (EP) originou-se a partir do âmbito privado. $O$ espaço doméstico como lugar da produção material da familia e lugar do culto é a célula da esfera privada, conforme Fustel de Coulanges (1975). Com a expansão da familia é que se formaram a gens, as fratrias, as tribos e, posteriormente, as cidades. Com estas é que surge o espaço público, a exemplo da polis grega, na antiga Atenas. Desse modo o "público" se consolida com base na constituição e expansão do "privado" e jamais poderia existir uma esfera pública independente e autônoma. Na Grécia antiga, a existência da polis dependia do oikos. Para que os cidadãos pudessem dedicar-se aos assuntos da cidade, era necessário que escravos, mulheres e crianças cuidassem da vida doméstica, do oikos.

Pelo visto, no passado, o "privado" exerceu grande importância, sendo o "público" uma conseqüência daquele. No entanto, o fenômeno das cidades suplantou a relevância do oikos. Tanto é que, em Atenas, a polis era o lugar por excelência da vida pública, sendo o oikos considerado lugar da ignomínia, da privação das faculdades da liberdade de expressão e da igualdade.

0 panorama atual apresenta elementos que remetem à situação original da predominância dos atributos privados da vida humana, embora as circunstâncias econômicas e culturais sejam outras. Atualmente, ao tempo em que se privilegia a privacidade, não há isolamento da vida públíca. Por outro lado, esta não requer a presença dos indivíduos. Não é mais necessário ir à praça pública ou a qualquer outro lugar para saber o que está acontecendo na sociedade. No caso da política, por exemplo, não é mais preciso sair de casa, expor-se em público, para ouvir os políticos e tomar

- Mestrando em Comunicação na Universidade de Brasilia

\begin{tabular}{|l|l|l|l|l|l|}
\hline VERITAS & Porto Alegre & v. 40 & $\mathrm{n}^{2} 157$ & Março 1995 & p. 87-111 \\
\hline
\end{tabular}


conhecimento dos fatos relativos a essa esfera. É a nova constelação pós-moderna da Esfera Pública.

Com a consolidação do aparato eletrônico dos meios de comunicação, a política foi "privatizada". No aconchego do lar, é possivel informar-se e ainda ouvir os depoimentos dos políticos. Até a linguagem da política mudou. Nada mais de oratória e discursos formais. Adota-se um tom coloquial e íntimo, como se o politico estivesse na casa e na presença real do cidadão.

É a partir dessa perspectiva que pretendemos desenvolver o tema "Esfera Pública, mídia e cidadania", com o objetivo de analisar o papel da mídia no contexto atual brasileiro no que se refere a essa questão.

Para tanto, procedemos inicialmente a uma breve abordagem sobre os três momentos hístóricos da Esfera Pública, conforme a periodização de Freitag (1993): o momento grego, o momento burguês e o pós-burguês. Essa periodização é detalhada a partir do legado de Hannah Arendt e de Habermas.

Em seguida, apresentam-se algumas reflexões sobre o panorama atual, com a finalidade de abordar a situação do Brasil quanto à relação entre Esfera Pública, mídia e cidadania. Para isso, analisamos os limites das empresas de comunicação que, na condição de empresas privadas, têm como objetivo prestar um serviço de conotação pública, visto que a informação em si, mesmo sendo tratada como mercadoria, possui uma dimensão acentuadamente pública.

Nas considerações finais, apresentamos uma síntese dos problemas considerados básicos no transcorrer da discussão, tais como o poder da mídia de construir um espaço próprio de publicização dos fatos de interesse público; os limites da informação mediática em termos operacionais; o tratamento episódico e fragmentado aos temas referentes à questão da cidadania e o possivel estabelecimento de um princípio de paridade via consumo.

\section{2 - O legado de Hannah Arendt}

Em A condição humana, Hannah Arendt (1983) dá uma ênfase especial à questão do espaço público. Espaço este que tem como função "iluminar a conduta humana, permitindo a cada um mostrar, para o melhor e para o pior, através de palavras e ações, quem é e do que é capaz" (Lafer, 1983, p. I). Nessa acepção, o espaço público é, antes de tudo, a esfera do comum, ou seja, tudo o que, através de ampla divulgação, tornase conhecido por todos. A aparição pública é, pois, na concepção de Arendt, condição básica para a consolidação desse espaço comum, visto que "para nós, a aparência - aquilo que é visto e ouvido pelos outros e por nós mesmos - constitui a realidade" Arendt, 1983, p. 59).

A abordagem de Arendt sobre essa questão se justifica pela concepção de que a percepção que temos de realidade é condicionada pela aparência, isto é, por tudo aquilo que é levado ao domínio público. Daí a importância da categoria "esfera pública" na referida obra de Arendt, pois é nessa esfera que os fatos, as opiniões, os argumentos e as pessoas emergem da obscuridade da esfera privada e adquirem interesse público.

A dimensão pública, porém, não se esgota aí. A autora aponta outra conotação, argumentando que o termo público significa também o próprio mundo, visto que este é comum a todos os homens, embora cada um ocupe um lugar diferente nele. 
"Bste mundo, contudo, năo é idêntico à terra ou à natureza como espaço límitado para o movimento dos homens e condição geral da vida orgânica. Antes, tem a ver com 0 artefato humano, como o produto de mãos humanas, com os negócios realizados entre os que, juntos, habitam o mundo feito pelo homem. Conviver no mundo significa essencialmente ter um mundo de coisas interposto entre os que nele habitam em comum, como uma mesa se interpöe entre os que se assentam ao seu redor; pois, como intermediário, o mundo ao mesmo tempo separa e estabelece uma relação entre os homens" (Arendt, 1983, p. 62).

Essas duas acepções de público podem ser consideradas distintas ou indistintas? Aparentemente, são idênticas, mas a autora estabelece sutis diferenciaçōes, destacando, no entanto, que há íntima correlação, ao que se pode acrescentar que existe uma complementariedade entre ambas. Onde estariam as distinçôes e as correlações?

Procedendo-se a uma interpretaçāo do que a autora escreve sobre as duas acepções, um elemento básico para distinguir a primeira da segunda são as noções de aparência e realidade, entendidas, aqui, não separadamente, mas combinadas, visto que o que aparece é o que se torna real na esfera pública. Nesses termos, pode-se dizer que aparência é igual a realidade, considerando-se que o que permanecer fora do foco dos holofotes da ribalta do espaço público jamais se tornará real, ou seja, de domínio público. Em suma, a publicidade (no sentido de tornar público) é a condição para a aparência e esta, a condição para se tornar real (conhecido). Isso constitui a peculiaridade fundamental da primeira perspectiva, o que a distingue da segunda.

Essa distinção evidencia-se no fato de que o mundo (elemento-chave da segunda concepção) não precisa ser publicizado para se tornar real. Todos os seres humanos têm consciência da existência dele, em termos genéricos, embora desconheçam aspectos específicos, em maior ou menor grau. A rigor, em termos materiais, ele não precisa de um espaço de aparência para se tornar real, já que é tão concreto, mesmo para o individuo que apenas se apercebe do lugar que ocupa nesse mundo. $O$ camponês que nunca saiu de sua roça ou o índio que jamais deixou sua tribo sabem que $o$ mundo tem existência real.

No entanto, uma concepção não exclui a outra, pois são complementares e correlatas. O camponês que ouve rádio ou vê televisão, por exemplo, depara-se com outros fatos que extrapolam seu minúsculo espaço físico, tão real e tão concreto como sua casa. O noticiário cria um espaço de aparência, tornando real para ele o que ocorre em outros lugares: a violência nas grandes cidades, a guerra, a fome, a seca, a corrupção, a inflação, o avanço das pesquisas científicas e tecnológicas, as grandes invençōes. Assim, os homens se apercebem do fato de que o mundo não é apenas a soma de elementos físicos: terra, água, ar, fauna e flora, mas um espaço de ação que agrega uns e desagrega outros. No entanto, não pode haver esfera pública sem a presença de outros individuos, pois o mundo nessa concepção não é algo que existe por si só, mas depende de ações humanas do passado e aponta para o futuro.

Há, portanto, uma dimensão política que transcende a mera existência humana, em sua dimensão puramente biológica. Os animais, por exemplo, não conseguem formar uma esfera pública, um mundo comum, na acepção aqui empregada. Os homens são condicionados por aquilo que aparece, que se torna público e pelos artefatos que constróem ao longo da História. Poder-se-ia imaginar a vida humana, hoje, sem eletricidade, sem trabalho, sem cidades, sem comércio, sem medicina, sem meios de transporte e de comunicação? Os animais, ao contrário, se permanecerem em uma selva, isolados de tudo isso, até viverão melhor. 
Mais uma vez Arendt apresenta um belo argumento para tal questão, inspirandose no modelo grego de esfera pública, a polis. A preocupação dos gregos com a instância pública reflete a necessidade de afirmação diante de um mundo provisório e fútil, o oikos ou esfera privada, lugar da necessidade, da miséria da condição humana: a mortalidade, o labor, a reprodução material das condições materiais de vida, a dimensão biológica. Em contraposição a isso, a polis, ou seja, o estabelecimento de uma esfera pública, um mundo comum constituía uma espécie de proteção contra a crueldade desse espaço de futilidade, mundo transitório e efêmero, mera existência humana. $\mathrm{O}$ acesso à polis significava uma superação de tudo isso, por meio da conquista de um status de "imortalidade", ou pelo menos relativa permanência, já que a esfera pública era a garantia de que os feitos notáveis ou as palavras memoráveis dos cidadãos não cairiam no esquecimento, mas se projetariam no futuro, através da dimensão histórica da cidade-estado. É, pois, um lugar de expressão da singularidade individual embora também se relacione com a esfera privada, pois era o oikos que permitia a existência da polis. Para que cada cidadão pudesse se dedicar à ação e ao discurso, os escravos, as mulheres e as crianças tinham de cuidar das obrigaçōes do âmbito privado.

Para entender melhor tudo isso, é fundamental a referência ao conceito de liberdade, apresentado por Arendt, na obra citada, conceito-chave para se apreender a essência do pensamento da autora sobre o problema da esfera pública. Por isso, trata-se de algo de conotação essencialmente política, pois

"só pode ser exercida mediante a recuperação e a reafirmação do mundo público, que permite a identidade individual através da palavra viva e da ação vivida, no contexto de uma comunidade política criativa e criadora" (Lafer, 1983, p. II).

Por isso, a polis grega é apresentada por Arendt como o modelo ideal do exercicio da liberdade, pois possibilitava a todos os cidadãos, por meio do estatuto da igualdade jurídica, expressar sua singularidade humana. A igualdade jurídica figura, pois, como condição para a liberdade que se efetiva entre pares, cidadãos livres das privaçōes do oikos como o trabalho (fabricação) e o labor (reprodução do ciclo biológico da vida).

A liberdade, assim entendida, não se confunde com a idéia atual de ser dono do próprio nariz, pois o aspecto público é que constitui o seu eixo e não o privado. Por isso, o medium da liberdade é a ação (terceira atividade fundamental da "vida activa", depois do labor e do trabalho; o primeiro é marcado pelas necessidades biológicas e pela futilidade da vida: é o reino do animal laborans; o segundo diz respeito à criação de objetos materiais a partir da fabricação: é o reino do homo faber. A ação é a única atividade que pode ser realizada sem a mediação de coisas e objetos, visto que corresponde à condição humana de pluralidade e singularidade, simultaneamente, essência da vida política, na esfera pública. Esse terceiro elemento é, portanto, a fonte de significados da vida, vinculada à dimensão histórica: memória da "vida activa", cuja fonte é a ação comum, no espaço público.

Logo, a ação é fundamentalmente política, bem como a palavra, o discurso a ela associados. Afinal, quem fala entre pares é que participa da esfera pública. É o discurso que faz do homem um ser político, um ser que se revela em sua singularidade no espaço da aparência, na presença de outros, na pluralidade. Eis o que diz a própria Arendt sobre isso: 
"A pluralidade humana, condiçăo básica da ação e do discurso, tem o duplo aspecto de igualdade e diferença. Se não fossem iguais, os homens seriam incapazes de compreender-se entre si e aos seus ancestrais, ou de fazer planos para o futuro e prever as necessidades das geraçōes vindouras. Se não fossem diferentes, se cada ser humano não diferisse de todos os que existiram, existem ou virăo a existir, os homens năo precisariam do discurso ou da açăo para se fazerem entender. Com simples sinais e sons, poderiam comunicar suas necessidades imediatas e idênticas" $^{*}(1983$, p. 188).

O elogio da ação, na perspectiva da polis grega, não é gratuito para Hannah Arendt. Pelo contrário, trata-se de algo fundamental para a compreensão do modelo histórico apresentado, sobretudo no que se refere especificamente à relação entre liberdade, ação e discurso. Isso porque somente o homem, gozando de igualdade entre pares, é capaz não só de comunicar-se com os outros, mas também de comunicar a si próprio. Assim, os seres humanos conseguem manifestar-se uns aos outros não como objetos, mas como sujeitos, dotados de uma subjetividade singular, o que não impede que haja pluralidade. Pelo contrário, o exercício da liberdade, por meio da ação, garante a coexistência de identidades pessoais e singulares com o interesse público, no espaço da aparência, onde, por meio da palavra, todos podem tornar real (público) o seu discurso. É importante ressaltar ainda que ação e palavra (bem como a própria liberdade), na perspectiva apontada, não devem ser tomadas como dados independentes, mas que dependem de um espaço público para existirem.

Tal argumento remete à questão do poder no pensamento de Arendt. Como já foi abordado, a liberdade é o elemento-chave para a existência da EP, sendo que a ação é o seu medium e a palavra e o discurso, aspectos básicos da ação. Essa cadeia de elementos resulta em um fenômeno fundamental para a manutençăo da EP: o poder, entendido pela autora não como coerção ou despotismo, mas como "recurso gerado pela capacidade dos membros de umà comunidade política de concordarem com um curso comum de ação (Lafer, 1983, p. XI).

Nessa perspectiva, o poder, para existir, necessita da EP, espaço da liberdade pública de participação democrática: espaço do discurso e da ação. Nas palavras da própria autora, o "espaço da aparência passa a existir sempre que os homens se reúnem na modalidade do discurso e da ação..." (op. cit p. 211). E mais:

O poder só é efetivado enquanto a palavra $\mathrm{e} O$ ato não se divorciam, quando as palavras não são vazias e os atos não são brutais, quando as palavras não são empregadas para velar intençōes mas para revelar realidades, e atos não são usados para violar e destruir, mas para criar relaçōes e novas realidades (op. cit p. 212).

Essa citação é suficiente para demonstrar a relação entre poder e esfera pública, no pensamento arendtiano, entendendo-se tal esfera como um espaço potencial capaz de se constituir em qualquer lugar em que os homens se reunirem. Um dado interessante, pouco percebido por quem crítica o possivel caráter utópico de $A$ condição humana é que, ao caracterizar assim o espaço público, Arendt não se refere apenas ao modelo grego, o que se deduz pelo fato óbvio de que não era apenas na polis grega que havia esse espaço potencial de poder a partir da reunião de pessoas, formando um público. Trata-se de um pressuposto teórico válido inclusive para a atualidade.

Não se propõe, com isso, uma apologia cega ao pensamento de Arendt, mas uma leitura atenta da obra em questão demonstra o quanto suas idéias são consistentes e podem ser potencialmente aplicadas à época moderna, apesar das especificidades históricas. Até porque, no que se refere especificamente ao poder, ela diz que este é sempre um "potencial de poder", nunca uma entidade imutável e cristalizada, além de 
ser condicionado também por fatores de ordem material, como a construção de cidades e, conseqüentemente, suas modernas transformações.

Retomando-se a relação entre poder e EP, é indispensável destacar a idéia da autora de que o espaço da aparência, o espaço público é preservado pelo poder, pois, "sem o poder, o espaço da aparência produzido desaparecerá tão rapidamente como o ato ou a palavra viva" (op. cit. p. 216). Por que o poder preserva a EP? Porque ele reúne e congrega os homens, forma um público, já que as relaçōes de poder só se estabelecem na presença de pessoas reunidas. Só a força e a violência podem ser exercidas quando há dispersão dos indivíduos, já que nem uma nem outra requerem a existência de um espaço público para serem consolidadas.

\section{3 - Habermas e a esfera pública burguesa}

Habermas oferece uma importante contribuição teórica para a discussão desse tema, ao deter-se no segundo momento da evolução histórica da EP: o momento burguês, analisado em sua obra Mudança estrutural da esfera pública burguesa (1984), detendo-se especialmente em sua origem, evolução, estrutura, instituições e funçōes. Aqui, não abordaremos minuciosamente todos esses itens, pois isso exigiria um trabalho mais extenso. Limitar-nos-emos aos elementos estritamente necessários para a compreensão de seu enfoque teórico sobre a EP, conforme nosso objetivo.

Esfera Pública Burguesa (EPB) é concebida por Habermas como uma categoria típica de época, condicionada por diversos fatores históricos, tais como o reaparecimento do comércio na Europa Ocidental do século XI, rompendo com a fechada estrutura econômica do feudalismo, o que é analisado com mais pormenores por Ribeiro (1988).

Os fundamentos socioeconômicos da EPB figuram, então, como fatores que incorporam suas características básicas, enquanto categoria histórica bem como distintivos em relação ao modelo clássico grego da esfera pública como esfera política e da esfera privada como espaço do oikos que abrigava o labor e o trabalho. Mas, por que Habermas detém-se nos aspectos socioeconômicos da EPB?

Antes de tudo, é necessário esclarecer que essa EPB emergente é definida pelo autor como a esfera das pessoas privadas reunidas em um público:

"Elas reivindicam esta esfera pública, regulamentada pela autoridade, mas diretamente contra a própria autoridade, a fim de discutir com ela as leis gerais da troca na esfera fundamentalmente privada, mas publicamente relevante, as leis do intercåmbio de mercadorias e do trabalho social" (Habermas, 1984, p. 42).

A EPB surge em contrapartida à autoridade absolutista. É esta sociedade civil burguesa que exige a regulamentação pública das atividades e relações econômicas, até então confinadas à esfera privada do orçamento doméstico. A atividade econômica privatizada orienta-se por um intercâmbio mercantil mais amplo e controlado publicamente. As condiçōes econômicas, sob as quais ocorrem, agora, extrapolam a casa e se tornam, pela primeira vez, de interesse geral.

Essa EPB desenvolve-se principalmente na proporção em que o interesse público na esfera privada da sociedade burguesa não é mais percebido somente pela autoridade, mas também pelos súditos, que passam a reconhecê-la como sua própria esfera. Como a EPB é a reunião de pessoas privadas (os burgueses não tinham poder político, não governavam até então) que nela se relacionam, a EPB assume duas funçōes bási- 
cas: desenvolver a subjetividade do público, promovendo sua emancipação psicológica, e afirmar sua função crítica.

Habermas identifica dois momentos históricos distintos e correlatos no desenvolvimento dessa EPB. O primeiro, denominado "esfera pública burguesa literária" (EPBL) refere-se à constituição da pura EPP, excluindo a população em geral e vai até o século XVIII. Consiste em ampliar a autoconscientização da burguesia enquanto classe, promovendo ampla reflexão sobre sua vida social, a partir da esfera intima da familia. A leitura de textos opinativos de caráter literário em jornais, de romances psicológicos e de epistolas de familiares e amigos constituem uma introdução a esse processo de emancipação psicológica. a EPBL não possui ainda conotação política. Como afirma Habermas (1984, p. 44):

"ela é o campo de manobras de um raciocínio público que ainda gira em tomo de si mesmo um processo de autocompreensão das pessoas privadas em relação às genuínas experiências de sua nova privacidade".

O segundo momento, o da "esfera pública burguesa política (EPBP), a partir do século XIX, inicia com a expansão da EPBL, surgindo uma EP mais ampla, resultado do amadurecimento da prática vivida no âmbito da EPBL e tem a finalidade de afirmar a criticidade do público, problematizando a legitimidade do Estado, o uso público da razäo, a regulamentação da sociedade, a defesa de instituições públicas etc. Seu desdobramento é o jornalismo político-partidário. É o exercício por excelência da opinião nos debates políticos sobre o questionamento do poder absolutista e discussões sobre a cidadania. Essa EPBP aparece primeiro na Inglaterra, na virada do século XVIII para o XIX.

Um argumento central para a questão aqui abordada, na obra de Habermas, é o exercício da democracia e da cidadania na EPB. Ele estabelece uma correlação entre 0 problema democrático e a publicidade (no sentido de tornar público), visto que esta é um meio de se atingir a democracia, já que viabiliza o desenvolvimento de uma postura crítica dos indivíduos (público) face aos problemas concernentes à EP. Isso se dá pelo conhecimento público de tais questões, pois, o indivíduo só pode situar-se como cidadão à medida que toma consciência de si mesmo e do meio sociopolítico no qual está inserído. A democracia está vinculada a essa consciência individual, crítica porque as pessoas passam a pensar por si mesmas, à medida que também se tornam interlocutoras, no espaço público.

O enfoque habermasiano apresenta semelhanças com o de Arendt, quando esta refere-se ao "espaço da aparência e do poder", ou seja, o espaço público como locus da ação e do discurso que permitem as relações de poder na EP. A diferença é que Habermas pensa em termos de EPB, uma EP mais ampliada do que a polis grega, apesar de ainda excludente. Porém, ele detém-se à questão da publicidade, na fase da EPBP, supostamente mais democrática, já que mais ampla do que a EPBL. (Tudo isso será importante para discutir no próximo item o momento pós-burguês da EP e a mídia.)

\section{1 - A EPB e a imprensa burguesa}

A necessidade de informações sempre foi um dado fundamental na vida social, mesmo nas sociedades antigas, onde a curiosidade do público suscitou a tradição oral de contadores de histórias, trovadores, pregoeiros. Com a difusão da escrita, ampliaram-se as possibilidades de transmissão de mensagens. Para auxiliar a organização 
administrativa, tanto os grandes como os pequenos impérios da Antiguidade e da Idade Média criaram órgãos oficiais de coleta de informações. Através dos pregoeiros e arautos ou por meio de cartazes/editais, as informações de interesse coletivo eram levadas a público.

A margem dos órgãos oficiais, conforme Albert e Terrou (1990), emergiram as correspondências privadas que em pouco tempo ultrapassaram o âmbito estreito das relaçōes pessoais. Isso ocorre sob o impulso cada vez mais expressivo das trocas comerciais, sobretudo a partir do século XV, na Itália, com a crescente importância mercantil de cidades como Gênova e Veneza e o estabelecimento da primeira grande rota comercial do mundo.

Com a expansão das atividades mercantis surge a necessidade da troca de informações entre as pessoas envolvidas em tais empreendimentos. Essa é a razão pela qual Marcondes Filho (1984) diz que imprensa e capitalismo são irmãos gêmeos, ressaltando que a noticia surgiu como algo de natureza essencialmente infra-estrutural, já que servia de suporte para a atividade econômica, acompanhando o trânsito de mercadorias.

Criou-se um sistema de correspondência especifico para atender às necessidades desse público quanto a informaçōes sobre eventos, feiras, preços, produtos agrícolas, clima, inundações etc. A troca de cartas comerciais, que já existia desde o século XIV, foi transformada em um sistema corporativo de correspondência, organizado pelas associações comerciais. Eram os "correios ordinários" que, em dias determinados, distribuiam os avvisi, também denominados "cartas-jornais" - folhas manuscritas, copiadas várias vezes, dirigidas a um público determinado (privado), os comerciantes.

Assim, os grandes centros comerciais tornavam-se, ao mesmo tempo, lugar de troca mercantil e de intercâmbio de informaçōes. Essa necessidade crescia com a intensificação do comércio externo e o surgimento das bolsas e letras de câmbio. Esse sistema de trocas de informação era estritamente privado porque aos comerciantes não interessava a publicidade da informação. Só se tornavam públicas para as corporaçöes, as chancelarias urbanas e as cortes.

No final do século XV, porém, a burguesia percebeu que a informação também era uma mercadoria de grande potencial de rentabilidade, pois era cada vez maior a demanda por esse novo produto. As notícias manuscritas - oriundas de um grupo privado, destinadas a um público também privado - já não eram mais suficientes para atender a um público que aumentava progressivamente. Surgiram, então, as "folhas volantes impressas" ou "gazetas". Editadas sob a forma de pequenos cadernos de quatro, oito ou 16 páginas, às vezes ilustradas com gravuras em madeira, traziam não só notícias econômicas mas também notas sobre festas, guerras e "exéquias principescas". Albert e Terrou (1990) incluem ainda nessa fase os pasquins e os libelos, folhas volantes de conotação diferente das gazetas. Os primeiros relatavam fatos sobrenaturais, crimes, catástrofes e acontecimentos extraordinários ou anormais. Já os libelos alimentavam as polêmicas religiosas e políticas, sobretudo com a Contra-Reforma, no inicio do século XVI.

\section{2 - Da imprensa comercial ao jornalísmo literário}

A difusão pública de informaçōes passou a ser considerada jornalismo propriamente dito somente quando a produção de notícias passou a apresentar outros objetivos, além dos fins exclusivamente comerciais: a defesa de interesses políticos e ideo- 
lógicos. É quando a burguesia descobre que a imprensa é mais do que uma atividade empresarial: é um instrumento de propagação de idéias e valores de interesse da classe. Com isso, o jornalismo tornou-se um veículo político e passou a ser também portador de opinião da burguesia e não simplesmente transmissor de informação.

Houve, então, uma grande proliferação de jornais, já que eram empreendimentos de custos relativamente baixos, devido ao seu caráter artesanal. Outro fator importante era o hábito de leitura entre as familias burguesas. O desenvolvimento de uma noção e prática de privacidade domiciliar, favorecidas pela arquitetura e estilo das residências, propiciou o cultivo do hábito de ler. As reuniōes nos cafés, salōes, clubes de comensais, teatros, associações literárias e outras instituições serviam de eco a essas leituras. É a gênese da EPBL, cujo desdobramento resultaria na EPBP, quando se passa a problematizar o uso público da razão, a regulamentação da sociedade, a defesa de instituiçōes públicas etc.

\section{4-O momento pós-burguês da esfera pública}

Conforme a periodização de Freitag (1993), este é o terceiro momento histórico da EP, desencadeado com a própria crise da sociedade burguesa, após a implantação do Estado de Direito Burguês e suas implicaçōes socioeconômicas e políticas. Destas, a principal foi a progressiva e acelerada expansão da esfera social, iniciada ainda no período burguês. Porém, foi nesta terceira fase que houve o completo alargamento dessa esfera, identificada como mercado. Com isso, a principal instituição privada, a família, foi implodida, quando o econômico transbordou de seu seio e invadiu outros dominios. O próprio público foi alterado com essa invasão, passando a identificar-se mais com o estatal. Tudo isso, é claro, não surge por geração espontânea no periodo pósburguês. São decorrências da nova ordem socioeconômica instaurada no período burguês.

Essa nova ordem instalou uma relação de interdependência e de trânsito entre as esferas privada, social e pública. Enquanto na EP grega havia uma nítida separação entre oikos e polis (a primeira dava sustentação à segunda, mas não havia trânsito estrito de uma para a outra, já que as mulheres, escravos e crianças eram excluídos da segunda), na EPB passou a haver uma confusão entre as mesmas, ao ponto de surgir a esfera social como intermediária, partícipe de um âmbito e outro e ao mesmo tempo sem características rigorosamante privadas ou públicas. No período pós-burguês, então, isso se torna ainda mais acentuado, a ponto de o Estado tornar-se apenas mediador dos eventuais conflitos entre tais esferas, sobretudo no que se refere a conflitos de interesses econômicos, como aconteceu nas duas guerras mundiais. A política e a legislação econômicas passam a ser o cerne da atuação do Estado, tanto em nível nacional como internacional.

Essa é a razão pela qual Habermas atribui à questão econômica um papel determinante na mudança estrutural da esfera pública. O ponto de partida para essa inversão foi a implantação do Estado burguês, no século XIX, quando a burguesia deixa de ser classe subalterna e torna-se classe dominante, invertendo também seus interesses políticos típicos: igualdade, liberdade e fraternidade, conforme o lema da Revolução Francesa. Os interesses do Estado burguês deixam de ser universais e assumem dimensões bem determinadas, direcionando-se, sobretudo, para a questã̃o da produção.

Os meios de comunicação, integrados nessa realidade, ampliam suas bases industriais de produção. Fundamentados na lógica de mercado vigente, firmam-se 
como instituições de caráter empresarial. É a fase da "imprensa de negócios" que, a seguir, se caracteriza como imprensa de massa. O potencial lucrativo amplia-se, mas, por outro lado, torna-se uma atividade onerosa. A utilização da publicidade em grande escala vem compensar essa aparente desvantagem.

Essa fase caracteriza-se ainda por uma ampliação quantitativa dos meios de comunicação: formação de complexos industriais de produção informativa, desenvolvimento de agências de notícia; alta concentração de capital e de propriedade de tecnologia; extrema especialização das funçōes. Culminam com a constitucionalização dos meios de comunicação enquanto instituiçōes privadas de caráter público, com a possibilidade de intervenção do Estado e a conseqüente regulamentação de sua propriedade.

É então que ocorre a inversāo estrutural da base original das instituiçōes jornalisticas, correlata à mudança estrutural da EPB. A imprensa - que antes era de caráter privado mas voltada para interesses públicos, como a liberdade e a igualdade, fundamentos da imprensa de opinião, difusora dos interesses gerais da sociedade - torna-se empresa de cunho público, porém voltada para interesses privados, organizada sob os critérios do modo de produção capitalista já consolidado.

Essa inversão torna-se 0 eixo da capitalização da imprensa e de suas conseqüentes lacunas e deformaçöes, fruto da ideologização da atividade jornalística sob a justificativa da competência técnica. Isso teve reflexo direto na organização do caráter privado, industrial e tecnológico das empresas jornalísticas, modificando sua infra-estrutura, conduzindo à introdução da informática, exigindo maior especialização e divisão do trabalho. Como resultado desse processo, a imprensa torna-se cada vez mais vulnerável, como instituição pública, já que passa a depender do capital privado.

Em linhas gerais, a Comissão Internacional para o Estudo dos Problemas da Comunicação (1983), órgão da UNESCO, resume essa problemática nos seguintes tópicos: a questão da propriedade e do controle dos meios de comunicação, o seu caráter transnacional, a despolitização do público e das mensagens e a influência do poder econômico e político sobre a produção da mídia.

Quanto à propriedade e ao controle, este problema está diretamente ligado ao fenômeno da industrialização que proporcionou grandes transformações, sobretudo depois da II Guerra Mundial. Mesmo sendo empresas privadas, é comum que o Estado destine verbas para o pagamento de déficits das mesmas.

"A assistência do Estado ocorre de diversas formas, inclusive de algumas reduçőes fiscais de que carecem as outras indústrias, da publicidade oferecida pelo Estado e da subvençāo do preço do papel para jornal..." (Comissão...., 1983, p. 163).

O fenômeno denominado transnacionalização afeta praticamente todo o setor da comunicação, da mesma forma que em outros setores da economia. Existem, nas operações industriais e financeiras da comunicação, os centros que controlam a produção, os serviços e os mercados periféricos que os absorvem. No caso específico da imprensa, as agências de notícia se configuram como exemplo típico dessa transnacionalização. $\mathrm{O}$ fluxo de informações obedece aos critérios dominantes nos outros setores da indústria, priorizando as áreas desenvolvidas, em detrimento dos países periféricos, dividindo o mundo em países ricos em informação e países pobres em informação. Afinal, 95 por cento da Informação Científica e Tecnológica (ICT) que circula no mundo atual é produzido nos países do capitalismo central e apenas um por cento na América Latina (Araújo, 1991). 
Com a inversão estrutural da base da imprensa ocorre uma despolitização do público receptor das mensagens. O leitor passou da condição de sujeito ativo da política, agente do processo de produção de opinião política, como na fase da imprensa de opinião e da EPBL, para a condição de consumidor passivo dos bens produzidos pela indústria cultural. Há, pois, uma decadência do caráter público da EPB. "A esfera pública assume funçōes de propaganda. Quanto mais utilizada como meio de influir, política e economicamente, tanto mais apolitica ela se torna no todo e tanto mais aparenta estar privatizada (Habermas, 1984, p. 208).

\title{
5 - Mídia e esfera pública: reflexões sobre o panorama atual
}

Após essa breve caracterização dos três momentos históricos da EP, pretende-se analisar alguns aspectos do contexto atual, direcionando o enfoque para a problemática da mídia versus esfera pública, com ênfase para o campo político. Para isso, consideramos elucidativa uma correlação entre algumas idéias de Hannah Arendt e Habermas com a situação atual. Antes, porém, tentemos caracterizar a EP dos dias de hoje - se é que se pode falar nesses termos...

Partindo da noção de EP como o espaço comum, conforme Arendt, pode-se inferir que a mídia institucionalizada é que exerce a função de agente desse espaço, apesar de suas limitações e idiossincrasias. Com uma visão talvez um pouco romântica e utópica, a Comissão Internacional para o Estudo dos Problemas da Comunicação refere-se à Comunicação como:

\begin{abstract}
"fonte comum da qual se tiram as idéias, fortalece mediante 0 intercåmbio de mensagens 0 sentimento de pertencer a uma mesma comunidade. Traduz o pensamento em ato e reflete todas as emoçōes e todas as necessidades, dos gestos mais simples que permitem a continuidade da vida até as manifestaçőes supremas da criação... ou da destruição. A Comunicação, que reune o saber, a organizaçăo e o poder vincula no homem a memória das suas origens às suas aspirações mais nobres para uma vida melhor (...) Ela aponta para a libertação dos homens da necessídade $e$ do medo, reunindo-os num sentimento de participação comum e num mesmo impulso de solidariedade e de compreensão... (p. 3).
\end{abstract}

Mesmo reconhecendo que, na situação atual, sem algumas mudanças estruturais, a maioria da população de diversos paises não poderá usufruir de todos os benefícios da Comunicação, a referida Comissão insiste na concepção de que a imprensa e os meios de comunicação de modo geral são veículos que devem promover fundamentalmente a informação, a socialização, a motivação pessoal e coletiva, o debate e o diálogo, a cultura, a distração e a integração.

Considerando-se todos esses argumentos e tendo presente na memória a origem da imprensa e sua configuração atual, percebe-se o quanto esse ideal dos estudiosos da UNESCO se distancia dos interesses aos quais os veículos de informação estão atrelados, no Brasil e no mundo, visto que tais veículos, atualmente, assim como em seus primórdios, estão voltados quase que exclusivamente para a defesa dos interesses comerciais e empresariais.

No contexto atual, ainda há outros agravantes, pois, além de serem regidos pela lógica de mercado, os meios de comunicação são também instrumentos políticos e ideológicos. Tal constatação não escapa à atenciosa análise da Comissão. Os autores fazem até uma descrição dos processos, como a fragmentação, a descontextualização, a personalização e o uso de formas lingüísticas, termos técnicos, gráficos, tabelas e outros recursos que dificultam a compreensão crítica dos conteúdos noticiados. 
A questão central dessa discussão toda é a seguinte: o que justifica, de fato, a defesa desse ideal de que os veículos de informação devem ter como eixo a defesa dos interesses coletivos, dos valores culturais, assumindo um papel pedagógico na sociedade, como ocorria na época do jornalismo literário e da imprensa de opinião caracterizados por Habermas?

Enquanto a imprensa era exclusivamente comercial, na fase da esfera pública burguesa literária, tais elementos não estiveram presentes. Não faziam parte de seus objetivos. Foram incorporados durante a fase do jornalismo literário e da imprensa de opinião que surgem posteriormente. Vale ressaltar que, no último caso, não se tratava de um empreendimento comercial. Não havia como determinante o fator lucro.

Hoje, porém, a situação é, de certa forma (ressalvadas as diferenças históricas) semelhante à imprensa artesanal de caráter comercial, no que se refere ao item lucro. Isso, é claro, não exclui iniciativas particulares e até mesmo expressivas, de veículos de conotação literária e de opinião, como é o caso da imprensa operária e sindical, por exemplo. No entanto, os meios de comunicação, em seu sentido amplo, estão voltados para os fins empresariais, especificamente, além dos interesses daqueles que detêm os meios de produção e o poder político.

Tanto é que a imprensa, especificamente, como no caso do Brasil, não se dirige mais a uma sociedade genérica, a um público indeterminado. Primeiro, porque os jornais e as revistas de grande circulação apresentam tiragens baixíssimas, comparandose com o total de habitantes do País. Enquanto a tevê atinge cerca de 90 por cento da população, a tiragem média dos quatro jornais de maior circulação no Pais (Folha de São Paulo, O Estado de São Paulo, O Globo e Jornal do Brasil), conforme Rubim (1989), não chega a um milhão de exemplares por dia, cada um.

Como o objetivo da empresa é vender o jornal ou a revista, a fim de que esses veículos sirvam também de instrumento para o implemento da receita publicitária, direciona-se todo o conteúdo informativo para o público consumidor.

O jornal Folha de São Paulo (FSP ou Folha), por exemplo, é muito claro em seu "Novo manual da redação", no qual afirma que a FSP se dirige a seu conjunto de leitores, especificamente, e não à sociedade, já que jornal é um produto de mercado, voltado para o mercado. Segundo Otávio Frias Filho (apud Silva 1988), diretor de redação da Folha, se a atuação do jornal contribuir para o bem coletivo e social, tanto melhor, mas sua finalidade básica não é esta. Seu objetivo primordial é atender às necessidades de seu leitorado (assim como as cartas-jornais eram de origem privada, dirigidas a um público privado, os comerciantes). Por isso, as edições diárias devem conter informações úteis e necessárias para a vida concreta de quem compra o jornal, ou seja, o leitor deve ser o ponto de referência permanente.

Por essa razão, a FSP tem investido muito em constantes pesquisas de mercado, como salienta Mendes (1992), com a finalidade de conhecer seu público leitor e procurar atender a seus interesses. Daí resultou o chamado jornalismo de serviços, cuja expressão maior é o Folhão, edição de domingo, que traz cadernos especiais como "Veículos", "Empregos", "Imóveis", dentre outros. Isso demonstra que o jornal está mais interessado em atender às necessidades privadas de seu conjunto de leitores do que em tornar-se veículo de difusão cultural, instrumento educativo ou de interação social. Se essas dimensões são contempladas na prática do jornal em questão, é mera conseqüência do desdobramento de seus objetivos primordiais.

Até mesmo a ênfase que a Folha dá às questões políticas é justificada pelas constantes pesquisas de mercado que apontam um interesse crescente de uma grande 
parcela do seu público em relação ao assunto, sendo que a motivação básica desse público são os interesses particulares que permeiam as relaçōes politicas.

Considerando-se o engajamento da FSP na campanha das "diretas-já", em 1984, a atual postura do jornal parece contraditória. Porém, conforme os argumentos de Otávio Frias Filho, diretor de redação do referido jornal (apud Silva, 1988), o atual desempenho da FSP resulta de um processo de amadurecimento empresarial, marcado pela busca de sua identidade de empresa capitalista, a fim de consolidar sua racionalidade produtiva.

Esse projeto editorial foi inspirado na ideologia da eficiência gerencial das empresas numa sociedade de mercado. O livro de Lee Iacocca, Iacocca: uma autobiografia, lançado em 1984, foi a fonte principal de inspiração. O livio relata a experiência do famoso administrador de empresas que transformou a Ford e a Chrysler em duas das maiores organizaçōes empresariais do mundo.

A FSP, aliás, é um exemplo singular da imprensa industrial, descomprometida com interesses públicos estritos (embora não seja o único jornal com tal fisionomia). Trata-se, paradoxalmente, de um jornal que nasceu sob o signo da defesa da causa pública, fundado em 1921, durante o surto industrial que sucedeu a I Guerra Mundial, período que coincide também com o fim da Primeira República (Mota e Capelato, 1980). Até a época das "diretas-já", a FSP manteve essa conotação, ressaltando sempre a necessidade de defender os assuntos públicos.

A partir de então, a direção da empresa promove uma série de discussões e estudos internos, culminando com a proposição do "Projeto Folha", com a finalidade de racionalizar a questão técnica e operacional do jornal, efetivando a concepção de jornalismo como negócio e não como ideologia ou algo similar. Apesar de outros jornais apresentarem a mesma filosofia, a FSP foi o primeiro a assumir publicamente sua "política editorial privada", com a publicação da primeira versão do "Manual geral da redação", em 1986, explicitando sua concepção empresarial.

Como estratégia comercial, a FSP decíde praticar um jornalismo denominado apartidário, crítico, moderno e pluralista, a fim de conquistar leitores de todas as tendências políticas possiveis. O jornal resolve ainda modificar a linha editorial, priorizando informaçōes inéditas, exclusivas e de impacto, a fim de vender mais. Entre os critérios que definem a importância de uma noticia, segundo o "Novo manual geral da redação" (1992), estão: ineditismo - ou seja, a notícia inédita é mais importante do que uma já de conhecimento público; improbabilidade - a notícia menos provável é mais importante do que aquela que não apresenta surpresas; interesse - quanto mais pessoas possam ter sua vida pessoal afetada pela notícia, mais importante ela será; apelo - quanto maior a curiosidade que a notícia possa provocar, tanto mais importante ela será; empatia - quanto maior o número de pessoas que possam se identificar com o personagem ou a situação, mais relevante ela se tornará.

Isso demonstra que o centro de interesse da FSP não é mais o "público" mas o "privado". Até a época da campanha em prol das "diretas-já", a linha editorial da FSP estava mais relacionada com o contexto sociopolítico-econômico e cultural do País, ou seja, com a dimensão pública. A proposta básica era instrumentalizar os leitores para uma análise crítica da realidade socioeconômica, política e cultural do País, contribuindo para efetivar as transformações sociais no Brasil. O leitor, nesta fase, era visto como um elemento político e não apenas como um elemento econômico. A mesma concepção era aplicada à informação. 
Aos poucos, esse conceito foi sendo reformulado. A notícia passou a ser concebida não mais como um bem público, mas privado, visto ser elaborada por uma empresa comercial que, como tal, não foge à lógica do capital. Passou-se, então, a refletir sobre a prática jornalística como técnica e como profissão e não somente como uma ação coletiva de formação da opinião pública. A partir de então, a FSP passou a considerar noticias e idéias como "mercadorias a serem tratadas com rigor técnico" (Folha de São Paulo, 1992, p. 13).

Dispomos de dados mais detalhados apenas sobre a FSP. Porém, os demais órgãos de imprensa, bem como o rádio e a tevê seguem a mesma tendência, segmentando a programação, adequando-a aos interesses do público, conforme a faixa etária e nivel socioeconômico. Diante disso, cabe algumas indagações, como:

a) Com essa perspectiva, a midia pode ser identificada como agente de construção de uma esfera pública na sociedade atual?

b) A "publicidade" empreendida pela midia se coaduna com a tese de Habermas de que o ato de publicização é um meio de se atingir a democracia, já que assim se viabilizaria o desenvolvimento de uma postura crítica, vinculada à consciência individual de cada cidadão?

c) A mídia torna públicos os fatos de interesse público ou constrói um espaço de aparência próprio, veiculando seletivamente alguns elementos e suprimindo outros? pública?

d) Como fica a questão da liberdade de expressão e do discurso, própria da esfera

e) A informação sobre os grandes temas públicos são conseqüentes, ou seja, impulsiona os cidadãos a tomar alguma atitude ou apresenta-se mais como um convite à apatia e ao conformismo?

Em uma tentativa de pelo menos discutir as questōes apresentadas (já que respondê-las é quase impossivel), é necessário preliminarmente abordar o problema da existência ou não de uma EP na época atual, no contexto brasileiro. É certo que não se pode falar em uma EP no sentido estrito, mas em uma "esfera pública transformada", expressão mercadológica de uma indústria cultural despolitizada, enquanto instância de reunião e discussão pública, o que se acentua no caso do jornalismo, sob o signo da chamada "neutralidade jornalística". Assim, essa EP transformada é mais um setor econômico e industrial que coloca no mercado seus produtos próprios (Ramos, 1993).

Existem vários fatores que podem ser apresentados como contradições dessa "esfera pública transformada". O primeiro deles é a tão propalada democratização dos meios de comunicação. Ora, basta referir-se a esse tema para perceber-se que a mídia institucionalizada, no Brasil, não é democrática. Se não o é, como poderá promover e defender a democracia, o espaço comum, o direito de todos?

O segundo paradoxo está nas próprias condições de mediação. Por mais que os meios de comunicação pretendam apresentar-se como fórum de debate público, não o são no sentido estrito, pois não há como efetivar a participação de todos. Há as limitaçōes dos códigos e da técnica que processam a mediação dos cidadãos com os assuntos públicos. Além disso, o "espaço da aparência" criado e mediado é unilateral, quanto a sua constituição. São os próprios meios que estabelecem a pauta, a agenda dos fatos e argumentos que serão levados a público. Entre os itens escolhidos ainda são selecionados os aspectos, prismas e pontos de vista. Em suma, é uma mediação parcial e incompleta, na qual o receptor não pọde interferir. Não se trata de um fórum de deliberação política propriamente dito, mas apenas de um espaço de aparência 
mediático. Sendo assim, como pode a mídia ser considerada agente do espaço comum, da negociação e argumentação pública? Trata-se, pois, de um fórum que

\begin{abstract}
"pode ser apenas um monólogo com espelho, onde a interação seja apenas um fantasma de interaçăo, onde a negociaçăo seja nada mais do que um jogo de reflexos. No fórum estabelecido pelo meio, o meio enquanto sujeito de pretensões de validade não precisa argumentar, nem interlocucionar; pode falar e mandar ver sem jamais ouvir" (Gomes, 1993, p. 83).
\end{abstract}

Nessa concepção, tais meios dificilmente poderiam ser incluídos na perspectiva do agir comunicativo, no sentido habermasiano, tendo-se em vista o seu caráter acentuadamente estratégico.

Outra contradição está na própria natureza dos meios de comunicação: empresas privadas de conotação pública, o que é mais acentuado no caso do rádio e da televisão, já que são submetidos a um processo de concessão pública pelo Estado, regulamentado por lei. Os pressupostos básicos da legislação, de acordo com o que se pode inferir da Constituição Federal de 1988, é que a intervenção do Estado se justifica para garantir que a mídia não se torne objeto de monopólio ou oligopólio e que haja preocupação com o caráter educativo e cultural da programação, a fim de promover a cultura nacional e regional e os valores éticos e sociais, assegurando, inclusive, o direito privado, individual ou familiar, de se defender de programas que contrariem a moral. Entretanto, na política, observa-se que tais pressupostos são extremamente vulneráveis, pois o que importa mesmo, para a empresa, é a ética de mercado, cujo eixo é o interesse comercial, em consonância com a lógica capitalista de produção à qual as empresas de comunicação estão submetidas.

Essas consideraçōes servem também para se discutir a primeira questăo, posta anteriormente, a respeito da possibilidade de identificação da mídia com um agente de construção da EP, na sociedade atual. Pelo visto, tal possibilidade é muito relativizada pelos paradoxos apresentados, pois a noçăo de EP remete ao exercício da democracia, à participação efetiva no processo de negociação pública e na elaboração e regulamentação das leis. Essa "EP transformada". portanto, tem uma configuração pública sofrivel.

O caráter público estaria acentuado apenas no que toca à recepção do que é veículado, pois, em tese, todos têm acesso ao conteúdo, transmitido pela mídia. Mesmo nesse aspecto, ainda é possivel identificar limitações. A primeira delas é de cunho econômico. Grande parte da população brasileira não tem pleno acesso a todos os principais meios de informação. Somente uma pequena parcela da população pode adquirir jornais e revistas diários e semanais. E para estar informado suficientemente não basta ler um dos grandes jornais ou revista.

Se, por outro lado, a tevê e o rádio apresentam maior penetração social, além das limitações de horário, há o problema da rapidez e instantaneidade e superficialidade da informação, o que compromete a qualidade informativa. Quem quiser entender melhor o problema abordado terá que recorrer aos meios impressos, onde se encontram textos mais detalhados e analíticos.

Esse argumento, bem. como o raciocinio desenvolvido anteriormente, fornecem elementos para se discutir conjuntamente a segunda e terceira questões. Considerando-se 0 âmbito político, percebe-se que este passou a ser condicionado pela mídia, pois o "lugar da política se deslocou dos comícios, e mesmo do Parlamento, para integrar o espaço dos meios de comunicação, em particular na tevê" (Amorim, 1993, p. 177). A partir da indagação desse autor: "política, a prisioneira da tevê?", pode-se in- 
terrogar também: na "EP transformada", a publicidade dos fatos de interesse coletivo, a liberdade de expressão e o discurso tornaram-se prisioneiros da mídia?

A prioridade para a publicização, para o espaço da aparência mediático é, quase sempre, o espetacular e o conflitivo ou o cômico, o inusitado. Recorrendo ainda ao autor citado, há uma preferência exacerbada, principalmente na tevê, por falas abreviadas e respostas curtas, o que revela a submissão da política às leis de marketing, 0 que ocorre com a cumplicidade dos políticos, na ânsia de permanecerem em evidência. Para a tevê, cada vez mais, só é digno de se tornar público o que pode ser representado pela imagem, "o que leva a tevê, por um lado, a ignorar acontecimentos importantes e, por outro lado, a exaltar acontecimentos sem nenhuma importância, pelo simples fato de serem "plásticos'" (Amorim, 1993, p. 118).

Cabe perguntar se a imagem é suficiente para informar. $O$ autor já referido diz que nem sempre basta ver um acontecimento para se compreendê-lo, o que conduz a um questionamento sobre o papel da tevê, quando a preocupação desta é cada vez mais espetacularizar os fatos, levando-nos a assistir aos acontecimentos representados na tela, o que, por si só, não garante que se compreenda uma situação enfocada, pois se trata de uma "verdade mostrada e efêmera".

Será, então, a política vitima dos meios de comunicação, no contexto atual? Por que essa subordinação e submissão aos códigos televisivos e às leis do marketing? Vejamos o que diz Amorim (1993, p. 121):

"No Brasil, a experiência da campanha presidencial de 89 é ilustrativa. Collor se elegeu pela performance da mídia e pelo uso intensivo do marketing. B apesar de ser um político, se apresentou como nåo-político, atirando contra os políticos. Existem certas características da política que ajudam explicar por que esta se deixa seduzir pelo canto de sereia da tevê. [...] uma das regras da política, já revelada por Maquiavel ao príncipe, é dar-se a ver ou se mostrar. Porque o que é visto poderá ser acreditado e o que é acreditado poderá servir de base à legitimidade. $O$ contrário também é verdade: năo dar-se a ver significa a morte política. [...] morrer politicamente é ser relegado ao espaço do silêncio, da năo palavra, da năo-imagem. Quando se fica fora dos meios de comunicação se é eliminado politicamente".

Esta citação nos fornece alguns elementos essenciais para a discussão proposta, tais como o caráter de superpoder da tevê, sua atuação frente às demais instituições e sua capacidade de atuar na formação da cultura política.

A conotação de superpoder da tevê, capaz de submeter a política à sua lógica, revela não apenas a força da televisão, mas também a fragilidade e o esvaziamento das demais instituições, como os partidos, os sindicatos e os próprios poderes constituídos, que ficam expostos vulneravelmente aos megapoderes televisivos. Mas, até onde vai o domínio da tevê sobre a política e onde começa?

Os estudos a respeito dessa temática, no Brasil, ainda são pontuais e limitados, mas os mais significativos apontam para uma imbricação bem maior do que aparenta. Em primeiro lugar, trabalhos como os de Fausto Neto (1990), Lima (1990), Porto (1993), Rubim (1989) e Weber (1989) indicam que o principal mecanismo do poder da mídia em face à política é a capacidade de construir um cenário de representação política, engendrando concepções, idéias, valores e significados que são associados a priori ou paralelamente ao desenrolar dos fatos e processos, com ênfase para aqueles do campo eleitoral.

Para isso, a televisão não se limita ao âmbito noticioso. Utiliza-se principalmente dos espaços destinados ao entretenimento, como as telenovelas, para construir representaçōes sobre a vida política. Um caso analisado minuciosamente foi o da eleição 
presidencial de 1989, a respeito da qual Lima (1990, p. 33) desenvolveu a hipótese da vitória antecipada, argumentando que

\begin{abstract}
"As razões para o sucesso da candidatura Collor devem ser buscadas no cenário político que foí construido pelos mídias, especialmente a tevê, sobretudo a partir da decisão sobre a duração do mandato de Sarney pela Constituinte [...] Esse cenário já estava delineado em meados de 89 , bem antes do início do Horário Bleitoral Gratuito [...] e pelo menos seis meses antes da realização do Primeiro Turno".
\end{abstract}

Rubim (1989) e Weber (1990) destacam as novelas da Rede Globo de Televisão, como: "Vale tudo", "O salvador da pátria" e "Que rei sou Eu?". A primeira, veiculada no horário das $20 \mathrm{~h} 30$, no período de maio de 1988 a janeiro de 1989 , apresenta a impunidade do poder e do capital em um pais marcado pela burrice e a preguiça do povo. A segunda, que sucedeu a primeira no horário nobre, permaneceu no ar até agosto de 1989. Expôs questōes relacionadas ao poder político e à comunicação, introduzindo de forma explícita a questäo eleitoral. "Que rei sou eu?", veiculada no horário das 19 horas, paralelamente a "O salvador da pátria", reforçou a idéia de que o candidato ideal não precisaria apresentar, obrigatoriamente, vinculação com partidos políticos tradicionais. O essencial eram os atributos de juventude, força, esperteza, habilidade e uma boa dose de criatividade e improvisação.

Isso demonstra que a tevê dispöe de todo o tempo para cuidar da arquitetura desse cenário, enquanto os partidos políticos limitam-se ao Horário Eleitoral Gratuito, que pouca importância teria, diante de um cenário já estabelecido. Até nesse ponto, a política torna-se vítima das astúcias da tevê.

Desse modo, a tevê torna-se uma instituição politicamente mais poderosa do que os próprios partidos. Só que tudo é orientado por um conjunto de "pedagogias de despolitização e desqualificação da política" (Weber 1990). Assim, sua contribuição para a formação de uma cultura política é extremamente questionável.

É o que demonstra o trabalho de Porto (1993). Ao analisar o papel da tevê na eleição para prefeito de São Paulo, em 1992, esse autor tomou como campo de estudo o "Jornal Nacional" e a novela "Pedra sobre pedra", da Rede Globo, e o "Aqui, agora", um telejornal do Sistema Brasileiro de Televisão (SBT). A novela constitui o exemplo mais representativo dessa desqualificação da política. Ao entrevistar eleitores, o autor perguntou qual era a opinião dos mesmos sobre a referida novela que estava no ar na época da pesquisa. As respostas são sintomáticas e reveladoras, como demonstram os exemplos a seguir:

- "A novela é uma grande besteira, mas mostrou a politica;

- "políticos corruptos, como sempre";

- "o bom foi mostrar como os politicos agem... é assim mesmo (...) a política é suja assim mesmo";

- "a novela foi uma palhaçada, embora tenha dito a verdade sobre a politica. O prefeito, deputado, tudo oportunista e safado" (Porto, 1993, p. 14).

Um exemplo da própria novela explícita essa tendência, na fala da personagem interpretada pelo ator Marco Nanini, o deputado federal Ivonaldo, quando este decide levar sua amante para Brasília, sob a alegação de que precisava de uma secretária de confiança. Sua esposa lembra que a moça de "Resplendor" não sabe datilografar, ao que 0 deputado responde: " $\mathrm{E}$ alguém no Congresso sabe fazer alguma coisa, sweetheart?"

Tudo isso reforça a idéia de que a publicidade assim realizada não se coaduna com a proposta habermasiana de sua vinculação com a democracia, já que não se 
presta ao desenvolvimento de uma verdadeira postura critica dos cidadãos. Assim, de fato, a mídia cria um espaço de aparência próprio, realizando uma construção arquitetada para depreciar a atividade política de forma generalizada, reduzindo todas as instâncias da esfera política aos espúrios da corrupção e da incompetência.

\section{$\mathrm{E}$ a liberdade de expressão?}

Quanto à quarta questão, já vimos que, do ponto de vista da recepção, ainda não existem alternativas quanto à liberdade de expressão. Mas, como se pode analisar esse tema considerando-se os superpoderes de expressão da mídia? Oficialmente, não se fala mais em censura, daí vem a falsa e ingênua impressão de que os meios de comunicação são livres para se manifestar sobre todo e qualquer assunto, desconsiderando que há um jogo de interesses que subjaz ao discurso dos meios de comunicação, já que estes não atuam isolados, mas em consonância com outros conglomerados econômicos que defendem interesses especificos (inclusive interesses políticos).

Outro fato para o qual Chaú (1986) chama a atenção é a lógica de deixar os fatos na clandestinidade, suprimindo ou obscurecendo determinados aspectos e destacando outros, em detrimento da real informação, pois cria-se uma nova aparência para o real. Com isso, a própria linguagem torna-se um instrumento de censura, pois é utilizada a fim de que seja capaz de comunicar para silenciar. Não se negam mais os fatos, como se fazia antigamente, mas os mesmos podem ser apresentados de forma a velar as nuances indesejadas pelo emissor.

A quinta questão refere-se ao compromisso da informação com uma ação conseqüente, a fim de que aquilo que aparece em público năo se perca no esquecimento $e$ na apatia. Vamos, antes, tentar categorizar a informação política mediática. Para isso, nos utilizaremos das idéias de Keefer (1993). Em sua opinião, a informação sobre assuntos políticos pode ser classificada em:

a) policy information - diz respeito à substância das ações empreendidas, com ênfase para a conotação diplomática e habilidade para resolver problemas relacionados com a orientação política e/ou programa de ação em termos genéricos e específicos;

b) political information - refere-se aos efeitos, resultados ou decorrências do policymaking, tais como a política econômica, a política fiscal, a política de saúde, etc.;

c) operational information - relaciona-se com a localização, regulação e procedimentos cabíveis quanto a informações relatadas, oferecendo aos receptores possibilidade de ação e mobilização em prol de uma idéia ou fato notificado.

Isso significa que as pessoas só terão chance de participar efetivamente dos processos políticos se dispuserem de policy information e de operational information, ou seja, além de conhecer o assunto, é necessário saber como proceder para agir.

Ao analisar a situação americana, o referido autor constata que a mídia dificulta a participação dos indivíduos, ao invés de facilitar, pois não se registra nenhuma preocupação em informar a respeito de como, onde e quando agir e o que fazer para interferir, como cidadão, nos fatos relatados. Além disso, o grau e a qualidade da informação são questionáveis, já que não há interesse em analisar as notícias, mas apenas em jogá-las ao público, no afã do imediatismo e do sensacionalismo.

Essa descrição parece um retrato fiel do que ocorre no Brasil, dispensando maiores comentários. Ao proceder assim, é óbvio que a mídia não estimula a participação, mas a apatia e o conformismo, levando o indivíduo a crer que tudo o que ocorre no âmbito político está completamente fora de suas possibilidades de atuação. Cria-se 
uma relação de distanciamento, mesmo quando são feitas graves denúncias de corrupção. Ao cidadão cabe apenas exercer seu papel de espectador. "Já que política é algo muito sujo, é melhor ficar distante mesmo", essa parece ser a mensagem indireta da mídia.

\section{6 - Mídia, esfera pública e cidadania}

Toda essa reflexão conduz à questão da cidadania, entendendo-se esta como uma forma específica de pertencer a uma totalidade social determinada, na definição de Da Mata (1987), para quem o conceito de cidadania implica dois elementos fundamentais: a idéia de indivíduo, particularidade e a de regras gerais e universais, ou seja, um sistema de leis que vale para todos os cidadãos em qualquer espaço social.

Isso de certa forma remete à concepção de Hannah Arendt de singularidade e pluralidade (referindo-se à polis grega). No entanto, até mesmo pelo distanciamento histórico, um enfoque mais rico talvez seja possibilitado pelas diferenças em relação ao momento atual. Comecemos pela transformação que sofreram as concepções de público e privado. Enquanto na antiga Grécia, o estabelecimento de um mundo comum de uma EP era quase uma necessidade de afirmaçăo diante do mundo provisório e fútil do oikos, hoje, parece o contrário.

As pessoas estão intressadas mais nas futilidades de sua privacidade, pois o público tornou-se tão difuso e confuso que provoca insegurança, indiferença ou até mesmo medo. $O$ privado é que parece constituir o denominador comum no sentido de reunir mais elementos capazes de despertar a atenção de maior número de pessoas.

Só que esta nova noção de privado não se restringe mais somente ao oikos. O espaço público foi invadido pelos interesses privados, tornando-se cenário de açōes privadas, estimuladas pelo espírito consumista do capitalismo. Hoje, as pessoas saem de casa para o espaço público não para participarem de eventos coletivos, nas para vivenciarem experiências privadas em público: comer, beber, namorar, etc.

A mídia reflete bem isso. Tanto é que o tom predominante é sempre particular. A tônica é o privado, mesmo quando são abordados assuntos públicos. As novelas, mesmo tratando de temas políticos, exploram as micro-relaçōes, a vida familiar, as intrigas entre os adversários, a vida amorosa das personagens etc. Os jornalistas se deleitam, quando lhes cabe o papel de desvendar a vida privada de algum parlamentar envolvido em falcatruas e corrupção e o público prende a respiração quando assiste a noticiários com esse timbre.

Outro fator que se distingue da EP grega, que consistia de modo especial no exercício comum da cidadania (Ribeiro, 1988) é a relação casa x rua, tão bem caracterizada por $\mathrm{Da}$ Mata (1987). A polis se diferenciava da familia pelo fato de que todos os cidadãos eram considerados iguais, enquanto a familia consistia em uma desigualdade institucionalizada. Hoje, acontece o oposto. Como observa o autor citado, em casa, somos supercidadãos e na rua, subcidadãos. No espaço doméstico é que exercemos nossa condição de singularidade. Somos respeitados, reconhecidos, podemos reclamar atenção dos outros. $\mathrm{Na}$ rua, impera o anonimato, a impessoalidade, a não-singularidade.

Por outro lado, a família não tem como assegurar o pleno status de cidadão ao indivíduo, pois como tal, ele está sujeito a leis universais. Além dísso, considerando o alto índice de pobreza e miséria no Brasil, a familia, para muitos, não oferece nem se- 
quer as minimas condiçōes de vida a seus integrantes. Tanto é que muitos menores abandonam a casa, preferindo o espaço da rua.

O que se observa, portanto, é um exército de cidadãos desválidos, aos quais foi assegurado apenas a cidadania jurídica, abstrata, como diz a Constituição: "Todos são iguais perante a lei". Em termos econômicos e sociais, a cidadania está na estaca zero. Mesmo no âmbito jurídico ela é frágil. A igualdade de direitos e oportunidades ainda está fora do alcance de muitos brasileiros.

Há uma distância avassaladora entre os cidadãos e as instituições que, em tese, defendem ou cuidam de seus interesses. Diante disso, desponta a mídia que, em alguns momentos, incorpora a função de "defensora de uma população sem cidadania". É cada vez maior a inserção de reportagens e notícias sobre direitos do consumidor, tanto na tevê como no rádio e nos jornais. Alguns não passam do denuncismo sensacionalista. Mas como o cerne desse enfoque quase sempre são os interesses privados, desperta a atenção dos receptores, já que o ponto de convergência básico da sociedade contemporânea são os assuntos da esfera privada.

O telejornal "Aqui, agora", do SBT, é um exemplo desse engajamento na defesa de tais interesses. Diariamente, questöes privadas vêm a público, com o propósito de encontrar uma solução. Existe até um repórter setorista especializado no ramo. Entre os assuntos mais explorados estäo: ilegalidade em contratos de aluguel, briga de vizinhos e abuso contra os direitos do consumidor. Desse modo, a tevê passa a defender e a resolver as pequenas causas dos desvalidos.

Essa política do "Aqui, agora" foi consolidada a partir de pesquisas de mercado, nas quais se registrou os principais temas preferidos pelo público do telejornal. Entre estes, além da tônica da violência, despontaram as pequenas causas judiciais, em especial aquelas que tratam dos direitos do consumidor, o que não deixa de ser uma questão pública, já que o Código de Defesa dos Direitos do Consumidor foi estabelecido por lei. Porém, o eixo da abordagem jornalística do SBT são os interesses privados. Cada questão é tratada isoladamente, explorando toda a emoção possível dos envolvidos, com un desfecho em que a própria emissora é que aparece como a grande solucionadora do problema. A lei que assegura tais direitos é praticamente ignorada em sua dimensão pública.

Ainda no âmbito da mídia eletrônica, um exemplo típico da exaltação dos elementos da vida privada em detrimento dos aspectos públicos é o cinema de violência. Trata-se de um tipo de filme voltado preferencialmente para a juventude. Apesar de manter elementos do antigo faroeste hollywoodiano (como a perseguição e a liquidação do bandido), o herói do cinema de violência da atualidade não se identifica mais com um xerife, um chefe de polícia ou um caçador de gangster de uma comunidade determinada, a fim de proteger a ordem e a segurança em um contexto específico.

O herói de hoje é alguém que fala e age por si próprio, em um ambiente hostil, sem $\mathrm{o}$ apoio da comunidade circundante. É um sujeito quase onipotente e independente. Sua ação é resultado de sua própria personalidade, do seu próprio eu. É mais uma atitude privada, ligada a interesses pessoais do que uma ação condicionada por fatores sociais. Tais fatores, quando aparecem, sempre figuram em segundo plano. Não é mais a vontade geral, a consciência coletiva, o senso comunitário que impulsiona a ação, mas a vontade e a motivação pessoal. Dessa ação pode até decorrerem benefícios coletivos, mas não necessariamente.

Além disso, os filmes do gênero em questão apresentam uma violência vazia de conteúdo real. É uma violência abstrata. Pode-se até afirmar que é uma violência plás- 
tica, propícia á sublimação e evasão pessoal da platéia. É, pois, uma experiência estètica intima que alivia tensões e neuroses pessoais. Afinal, o filme não aborda problemas públicos, dramas coletivos. 0 herói individualista representa para um público também individualista, egocêntrico.

A bondade do herói foi humanizada, a fim de identificá-lo com o homem comum. Não tem poderes, quer apenas sua paz, revolta-se contra as injustiças e, como modelo cada vez mais usado de identificação com o espectador, é do estilo inspetor Columbo: maltratado pelo mundo, desrespeitado, desvalorizado (Marcondes Filho, 1993). Ao contrário do herói do antigo faroeste, o cinema de violência da atualidade procura identificar a figura heróica com o tipo joão-ninguém, representante ímpar da decadência do homem público e da frustração do projeto de plena cidadania no mundo moderno.

Seu objetivo é, pois, através dos personagens, interagir com o zé-povinho, dandolhe a confiança de que mesmo pequeno como Davi, tem poderes e potencialidades. Procura restituir, assim, a importância perdida do homem comum, ser anônimo e insignificante na geografia pública do cenário urbano moderno:

\begin{abstract}
"Diante da năo-participaçăo política efetiva (o único que faz, e quando faz, é votar, o que pouco altera sua vida, já que os políticos estão cada vez menos presos a compromissos eleitorais ou partidários), da sua total insignificância social, do seu anonimato, da miséria existencial de sua vida (mal empregado, sem posses, sem dinheiro, sem esperanças), das frustraçóes e decepçōes que tem que vivenciar, o cinema estimula no seu inconsciente um sonho antigo de sua infancia, a idéia da onipotência, segundo a qual tudo dependeria de seu controle...' (Marcondes Filho, 1993, p. 110).
\end{abstract}

Outro elemento intensamente explorado pelo cinema de violência é o atributo da virilidade. Já que os heróis são representantes do tipo joão-ninguém (Rambo, por exemplo, é um policial de baixa patente, ex-combatente no Vietnã, desprezado e humilhado) personalizam o poder viril. $\mathrm{O}$ homem comum não atingiu o status de plena cidadania, continua marginalizado econômica e socialmente, sem poder efetivo na vida pública. No entanto, a virilidade é um atributo privado, próprio de sua condição humana. Ninguém pode extirpar tal atributo. Faz parte de sua intimidade, talvez até como fator de auto-afirmaçäo em face à erosão da vida pública, da experiência coletiva.

O mesmo autor sugere ainda que esse aspecto viril dos filmes fascina os jovens do sexo masculino, estabelecendo uma admiração de caráter homossexual, embora nem sempre percebida. Isso estimula o narcisismo, levando muitos rapazes a cultuar o próprio corpo e o de seus heróis. Mas, "como a violência, também a virilidade é sígnica: é somente formalismo, virilidade de halterofilista e braços-de-ferro que podem esconder muito bem um narcisismo homossexual e estéril" (idem, p. 110).

Outra faceta dessa relação entre mídia e cidadania, considerando-se o panorama sociopolítico atual do Brasil, é a "cultura de crueldade", conceito do psiquiatra Jurandir Freire Costa (1993), ao formular uma concepção psicanalítica em nível coletivo. Argumenta que, nas relações que estabelecem hoje em dia, as pessoas vêem os outros basicamente de três modos: como um inimigo, como um ser inferior ou como instrumento de uso para a obtenção de lucro e beneficios. Um exemplo típico dessa manifestação seria a defesa do extermínio de menores de rua e de marginais, como medida contra a criminalidade e a violência urbanas, além dos atentados racistas, conflitos étnicos e movimentos separatistas desencadeados em várias partes do mundo. 
São decorrências extremas da falta de uma base sócio-econômica e política concreta para a consolidação da cidadania em sua totalidade. $\mathrm{E}$ a mídia reproduz diariamente essa "cultura de crueldade". As relações entre patrão e empregado, ricos e pobres, brancos e negros são, extremamente caricaturais e estereotipadas nos enredos telenovelísticos e cinematográficos, perpetuando o estigma da inferioridade cultural, sexual e racial. Entre os iguais a guerra tem a finalidade de mostrar quem é capaz de tirar mais proveito um do outro, seja nas relações amorosas, financeiras, sociais ou mesmo familiares.

\section{7 - Consideraçōes finais}

Diante do exposto, podemos destacar, como questōes-chave para finalizar a discussão proposta, os seguintes tópicos:

\section{a) a mídia constrói um espaço de aparência próprio, redimensionando o público e o privado.}

Esse espaço de aparência é altamente excludente. Primeiro, porque um jornal, emissora de rádio ou televisão veicula os fatos, opiniões e argumentos concernentes a questōes públicas de acordo com seus critérios privados de administração e gerenciamento da informação. A exclusão começa pela pauta: quem será entrevistado e qual será o enfoque adotado. Com a edição, esse processo se intensifica por meio da seleção das melhores falas e dos dados mais importantes. Isso permite que cada meio de comunicação apresente sua versão peculiar. Para ter uma noção mais abrangente do que aquela que aparece na mídia, seria necessário, no mínimo, que o receptor tivesse acesso aos principais jornais diários, revistas semanais e emissoras de rádio e tevê. Como isso na prática não ocorre, devido a diversos fatores, como falta de tempo e de dinheiro, a população fica excluída do grande espectro do fluxo informativo, limitando-se à versão de determinado(s) veículo(s) de divulgação pública.

Trata-se, pois, de uma esfera pública de natureza tão excludente quanto a polis grega ou a EPB, pois a democratização do estágio atual é mais aparente do que real, considerando-se que não basta ter acesso ao circuito informativo para assegurar a participação nas decisões públicas. Muitos brasileiros têm acesso à informação via tevê, no entanto, uma grande parcela permanece excluída do debate público, visto que nem é capaz de compreender o que está ocorrendo. Com o avanço dos meíos eletrônicos e 0 atraso sócio-econômico, grande parte da população passou direto da oralidade para a audiovisualidade, sem nem sequer aprender o domínio pleno da escrita.

Em suma, a mídia não constitui uma esfera pública stricto sensu porque não permite a real interaçäo dos homens por meio do discurso e da ação, na presença de outros. Limita-se ao uso estratégico da palavra e do discurso, tendo como meta, quase sempre, a persuasảo e não o entendimento.

b) A mídia pode ser metaforicamente entendida como um grande espelho que tudo reflete, mas cujo poder de alcance real, em termos operacionais, é limitado.

As limitações têm como substrato o próprio excesso de mensagens veiculadas. A emissão inflacionária de dados, fatos e opiniōes inusitados contribui mais para apassivar do que para ativar mecanismos de reação pública, salvo casos particulares, como o impeachment de um presidente da República ou um escândalo nacional, como um caso de corrupção na elaboração do Orçamento Público da União. Mesmo assim, o al- 
cance operacional da reação pública limita-se aos próprios veículos da mídia, passeatas e protestos de rua.

Em termos gerais, a avalanche informativa concentra-se na political information, em detrimento da policy information e, principalmente, da operational information. Dificilmente o cidadão é munido de dados instrumentais para uma ação coletiva que possa interferir nos processos da esfera pública. Ao contrário, a informação instrumental limita-se quase exclusivamente à esfera privada: indicadores econômicos e operações financeiras, viagens, problemas domésticos, investimentos, negócios etc. 0 chamado jornalismo de serviços, por exemplo, é todo direcionado para o consumo, concentrando-se em informações e cadernos especiais sobre veículos, imóveis, eletrodomésticos, finanças, casa e decoração, programação cultural, etc.

Trata-se de um eixo poderoso e importante da época atual. Isso é inegável. Não contestamos tal relevância. $\mathrm{O}$ que é curioso é que essa tendência meio didática, de orientação diária aos receptores, seja inexpressiva em outras áreas, como a política, por exemplo, que apresentam mais abertamente conotação pública estrita. Qual a razão para que os indivíduos sejam munidos de dados operacionais com fins específicos, como aplicações financeiras mais rentáveis e não de como agir para que a vida pública seja maximizada? $\mathrm{O}$ ganho, o benefício só interessa ao mercado e ao próprio bolso do cidadão? A Política não é mais um meio, para otimizar a vida pública?

c) A cidadania no discurso da mídia aparece como algo episódico e fragmentado.

Ao tempo em que a mídia assume as dores de um exército de "cidadãos desvalidos", impede o desenvolvimento de uma verdadeira consciência a respeito do que seja, de fato, cidadania. $\mathrm{O}$ discurso muda de acordo com o rumo do agendamento dos temas em pauta, diluindo, assim, a concepção do que seja cidadania, às vezes ampliando-a demais, às vezes reduzindo-a ao extremo.

$\mathrm{Na}$ época da censura e da repressão, ser cidadão significava ter direito à livre expressão. No período da campanha das "diretas-já", falar em cidadania era defender o direito de votar para presidente. Com o impeachment do ex-presidente Collor, ser cidadão era contribuir para a queda do presidente corrupto. A campanha do sociólogo Herbet de Sousa contra a fome e a miséria vinculou o problema da cidadania diretamente à fome...

Não seria sensato negar que tudo isso faz parte da noção de cidadania. O que é questionável é esse caráter episódico e fragmentado que a mídia dá a esses temas, singularizando-os, isolando-os de outros fatores correlatos, do conjunto maior de direitos e deveres inerentes ao fato de ser cidadão.

d) A "esfera pública transformada" baseia-se no princípio da paridade pelo consumo.

No estágio atual da sociedade capitalista, o econômico adquiriu tamanha importância ao ponto de transformar todos os homens em consumidores. Quase todos os aspectos da vida humana foram absorvidos pela lógica do consumo, até o sexo, o desejo, o sonho, a fantasia. Tudo foi absorvido pelas forças mercadológicas. A referência básica de todas as relações, a palavra-chave é mercado. Fala-se até em mercado politico.

Diante de tudo isso, a inferência lógica central é que o que ainda congrega os homens de hoje é o aparato do consumo. Inferência esta que pode ser estendida ao campo político. A democracia de massas se estabeleceu com base em um mercado político no qual a participação dos cidadãos se efetiva sob a lógica do consumo. Diante de todas as diferenças e desigualdades, surge algo que aponta para a tão propalada 
igualdade de todos os cidadãos: o consumo. Teoricamente, todos são consumidores em potencial e todos sâo iguais perante as leis do mercado. Em suma, todos são consumidores, de uma forma ou de outra. No caso da política, todos são consumidores, pelo menos de political information, via mídia.

É lógico que tudo isso se distancia muito do exercício comum da cidadania, da liberdade entre pares, na democracia grega. No entanto, parece ser o fundamento da sociedade atual. Todos que participam da "esfera pública transformada" participam através do consumo. Consumo de bens materiais e simbólicos, sobretudo os últimos: palavras, imagens, idéias...

Essa paridade, porém, em países como o Brasil, ainda é frágil, visto que as desigualdades econômicas são alarmantes. No entanto, nos países capitalistas centrais, onde as disparidades são menores, o consumo figura como o elemento básico no estabelecimento de relações na "esfera pública transformada", com especial ênfase para a indústria cultural.

\section{Referências bibliográficas}

ALBERT, P.; TERROU, F. História da imprensa. São Paulo: Martins Fontes, 1990. 121p.

AMORIM, J. S. D. 'A politica, prisioneira da tevê? - o mal-estar francês". In: PEREIRA, C. A. M., FAUSTO NETO, A. Comunicaçäo e cultura contemporâneas. Rio de Janeiro: Notrya/COMPOS, 1993. 318p. p. 115-126.

ARAÛ́JO, V. M. R. H. de. "Informaçăo: instrumento de dominaçăo e submissăo" Ciência da Informaçăo, Brasilia, v. 20, n. 1, p. 37-44. jan./jun. 1991.

ARENDT, H. A condiçăo humana. Rio de Janeiro: Forense-Universitária, 1983, 338p.

BBLL D. O evento da sociedade pós-industrial. São Paulo: Cultrix, 1973. 540p.

CHAUİ, M. "Imprehsa e democracia". Folha de São Paulo, São Paulo, 9 jun. 1986, p. A-6.

COMISSÃO INTERNACIONAL PARA O ESTUDO DOS PROBLEMAS DA COMUNICAÇÃO. Um mundo e muitas vozes: comunicação e informaçäo na nossa época. Rio de Janeiro: FGV, 1983. 499p.

COSTA, J. F. "Vivemos na cultura da crueldade" (entrevista a Marcelo Monteiro). Cadernos do Terceiro Mundo, Rio de Janeiro, v. 16, n. 165, p. 4-6. set. 1993.

COULANGES, F. de. A cidade antiga. Săo Paulo: Hemus, 1975.

DA MATA, R. C. da. A casa e a rua: espaço, cidadania, mulher e morte no Brasil. Rio de Janeiro: Guanabara, 1987.

FAUSTO NETO, A. "O presidente da televisăo". Comunicaçăo \& Política. São Paulo, v. 9, n. 11, p. 7-27, abr./Jun, 1990.

FOLHA DE SÃO PAULO. Manual geral da redação. 2. ed. São Paulo, 1988. 214p.

- Novo manual da redação. São Paulo, 1992. 331p.

FREITAG, B. "Periodização da Bsfera Pública". Brasilia: UnB. Anotaçōes em sala de aula. 1993.

"A função politica da imprensa" In: MARCONDES FILHO, C. (Org.) Imprensa e capitalismo. São Paulo: Kairós, 1984. 170p. p. 23-40.

GOMES, W. "Pressupostos ético-políticos da questão da democratização". In: PEREIRA, C. A. M., FAUSTO NETO, A. (Org.). Comunicaçăo e cultura contemporâneas. Rio de Janeiro: Notrya/COMPÓS, 1993, 318p. p. 47-94.

HABERMAS, J. Mudança estrutural da esfera pública. Rio de Janeiro: Tempo Brasileiro, 1984. 397p.

KBEFER, J. D. "The news media's failure to facilitate citizien participation in the congressional policymaking process". Journalism Quarterly. South Carolina, v. 70, n. 2, p. 412-24. 1993.

LAFER, C. "A politica e a condição humana". In: ARENDT, H. A condição humana (introdução). Rio de Janeiro: Forense-Universitária, 1983, 338p. p. I-XII.

MARCONDES FILHO, C. O capital da notícia: jornalismo como produção social da segunda natureza. 2. ed. Săo Paulo: Ática, 1989. 188p.

- . "O cinema de violência". Comunicaçăo \& Política, São Paulo, v. 11, n. 18-19, p. 107-113, 1993.

MENDES, A. M. T. "O homem do DataFolha" (Entrevista a Luiz Egypto). Imprensa, São Paulo, v. 5, n. 3, p. 71-73. mar. 1992.

MOTA, C. G., CAPELATO, M. H. História da Folha de São Paulo. São Paulo: Impress, 1980. 416p. 
PORTO, M. "O papel da televisăo na eleiçăo de 1992 para prefeito de São Paulo". Cadernos de mídia e politica. Brasilia: UnB, v. 1, n. 1, julho, 1993.

RAMOS, M. C. "O paradigma da indústria cultural no século XX: do rádio à televisão". Brasilia: UnB. Anotaçōes em sala de aula. 1993,

RIBEIRO, L. M. Imprensa e esfera pública burguesa. Brasilia: UnB, 1988. Dissertação de Mestrado.

RUBIM, A. A. C. "Comunicaçáo, espaço público e eleições presidenciais". Comunicaçăo \& Politica. São Paulo, v.9, n. 2,3,4. jun./set./dez. p. 167-186. 1989.

SILVA, C. E. L. da. Mil dias: os bastidores da revoluçāo em um grande jornal. São Paulo: Trajetória Cultural, 1988. 218p.

WEBER, M. H. "Pedagogias de despolitizaçăo e desqualificação da política brasileira: as telenovelas da Globo nas eleiçōes presidenciais de 1989". Comunicaçăo \& Política, Sảo Paulo, v. 9, n. 11. abr./jun. 1990. p. 67-84. 